\title{
The Nakṣatra System in the Vedic Calendar
}

\author{
SAKAмото-Gotō Junko
}

1. [Here is a sequel to "The Vedic Calendar and the Rituals (1)" JIBS 58-3, 2010, $1117 \mathrm{ff}$.]

In the Vedic calendar until about the $5^{\text {th }}$ century B.C., the date is determined by the moon's phase and position relative to the stars on or near its path. Special importance is set on two

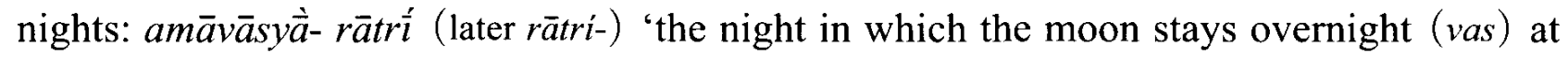
home $(a m \dot{a})$,' i.e. 'the night of the moon's conjunction with the sun,' and paurnamăsírātrí (rātrí) 'the full moon night in which the moon is in opposition to the sun.' These are the sacred nights for upavasathá-'staying overnight near the sacrificial fire with religious observance' (hence, the Uposatha in the Buddhism/Jinism) and, the next morning, the New or Full moon sacrifice as well as other Śrauta rituals are performed (cf. ĀpŚS X 2,8, etc.).

It is, however, not easy to decide the Amāvāsyā or Paurnamāsī night. The period between two successive conjunctions with the sun (i.e. lunation $=$ synodic month) is on average about 29.53 solar days. The moon's conjunction and opposition may occur any time, in the night as well as in the daylight. In the latter case a vexed question arises whether the preceding or the following night is valid as the Amāvāsyā or Paurṇamāsī. It becomes all the more difficult as various factors change independently, i.e. time of sunset/-rise, time of moonrise/-set, angle between the horizon and the ecliptic, divergence of the moon's orbit from the ecliptic. The problem is more serious for the Amāvāsyā night, for the thin moon in the twilight just before and after the conjunction may easily escape from the naked eye, even not disturbed by the weather. This difficulty required to watch the moon every night with careful attention, which brought forth the knowledge on its movement with reference to the sun and the fixed stars: after the conjunction with the sun, the newly appeared moon moves from west to east in its orbit, approaching every night a different star or star-group, until it joins again with the sun. The nights in which the moon is visible number on average 28 in a synodic month. The moon was thus considered to visit every night a different star (-group) situated on its path during 28 nights and to stay at home with the sun in the Amāvāsyā night. The stars as well as the sun at which the moon stays are named nákșatra- nt. 
'place (suffix -tra-/-atra- $)^{1)}$ to which [the moon] attains $\left(\right.$ náksa $a^{{ }^{i}}{ }^{2}{ }^{, 2)}$ (commonly translated "Mondstation," "Mondhaus" or "lunar mansion"). While the star in general is expressed by the word of Indo-European origin $\left({ }^{*} h_{2}\right.$ stér-), stár- (RV: stŕbhhih, tâarāh ), later táarakā- (AV+ ) and $t \bar{a} \bar{a}-(\mathrm{Cl}$. Skt.), nákșatra- means 'the heavenly bodies of special kind related to the moon,' originally inclusive of the sun as attested in the Rgveda [RV] $(\rightarrow 2$.), then 'the remarkable star (-group)s situated approximately equidistant on or near the moon's path., ${ }^{3 \text { ) }}$ This notion itself must go back to very old times beyond Vedic age, maybe to those of the Indo-European common stage, as the Nebra Sky Disk in the European Bronze Age (completed ca. 1600 B.C.) suggests. ${ }^{4)}$

As above mentioned, the moon visits 28 Naksatras (except the sun) in a synodic month, from which results the system of 28 Nakștras. This model accessible to the common people seems have been favored in popular ceremonies $(\rightarrow 3 ., 6 ., 7$. $)$. On the other hand, the observer of celestial bodies recognized another cycle of the moon's movement related to the star, i.e. the sidereal month (on average ca. 27.32 solar days), which lead to the system of 27 Nakșatras. This more scientific model have prevailed among the priest-scholars $(\rightarrow 4 ., 5$. $)$. Each system has a defect: the 28 Nakṣatras based on the synodic month is disaccord with the moon's relation to the stars, while the 27 Naksatras based on the sidereal month diverges from the date of synodic month. Efforts to resolve this contradiction are revealed in the Yajurveda [YV] texts examined below. Leaving questions of the number aside, members of the Nakṣatras seem to have been not fixed in their early stage except for several important and characteristic star(-group)s such as Kị́ttikās. They seem to have been systematized as the popular worship of the Nakșatras developped and to have been partly taken into the Śrauta rituals $(\rightarrow 2$.). nákșatra-in pl. is sometimes used in generalized meaning as synonym for stár-/tárakā- $(\rightarrow 2.) .^{5)}$ For the heliacal rising, s. 6.

2. The RV, which has a strong tendency to avoid mentioning what concerns the night or darkness, does not inform us much of the stars. Beside stár- ( 7 times in pl.), nákṣatra- are attested 10 times: all the 6 forms in sg. (VI 67,6 masc.; VII 81,$2 ; 86,1 ; X 88,13 ; 111,7 ; 156,4$.) imply the sun (súrya-); of the 4 forms in pl. (I 50,2; III 54,19; X 68,11;85,2), the sense 'lunar mansion' is evident in X 85,2 of the Sūkta on the Moon's marriage with Sūryā, in which two Nakṣatra names are mentioned: X 85,13 aghä- 'evil' f.pl. and árjuni- 'silver colored' f.du. ( AV XIX 1,13 maghă- and phalguni-; $\rightarrow$ 3.), s. Ved.Cal. (1) 3.2. Two vocatives punarvasu and revatih in $\mathrm{X} 19,1$ have nothing to do with the Naksatra; the former is an epithet of Agni and Soma, the latter of the cows. tiśyà- m.sg. in V 54,13 and X 64,8 is consid- 
ered as a different star from the $6^{\text {th }}$ Nakṣatra tiṣyà-/tișya-. ${ }^{6)}$ The enigma hymn I 164,16 implies $k \dot{r} t t i k \bar{a}$ - f.pl. 'spinner women,' but not as a Nakșatra.'

It is striking that the Nakṣatras are enumerated only in supplementary parts of the Atharvaveda $[\mathrm{AV}]$ and the Black YV (mantra- and prose-portion). They all begin with Kŕttikās (identified as Pleiades situated at the spring equinox about 2300 B.C.) and show a remarkable affinity to each other with regard to members, their order and divinities; they are divided into two groups: 28 Nakșatras with Abhijit and 27 without it, s. Synopsis at the end. ${ }^{8)}$ Though Abhijit is identified as Vega (Lyra $a$ ) by the classical astronomy, it is yet an open question which star the Vedic Abhijit is, for different stars are called by the same name as tisyà- and rohinít-. Vega (ecliptic latitude $+61^{\circ} 44^{\prime}$ in A.D. 2010) is too remote from the moon's orbit to be a Nakșatra. Cf. Abhijit TB ${ }^{\mathrm{p}}$ I 5,2,3 $(\rightarrow 7$.$) , abhijáyat and abhijitam$ TB $^{\mathrm{p}} \mathrm{I}$ 5,1,4 $(\rightarrow 6$.$) .$ It is also the name of a Soma sacrifice performed in the $6^{\text {th }}$ month of the Gavāmayana.

3. A list of $28^{9)}$ Naksatras appears in AV XIX 7 in the Śaunaka recension. This hymn for daily worship of Nakșatras $(\rightarrow 7$.) belongs to the latest stratum of the AV.

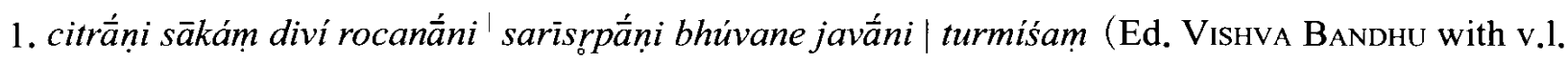
turmicham, WHITNEY emends to astâ̄vimsám according to XIX 8,2 $\rightarrow \mathrm{n} .9$ ) sumatím icchámāno' áhāni

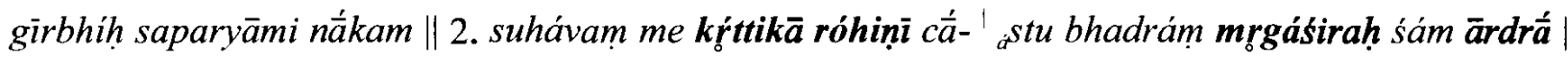

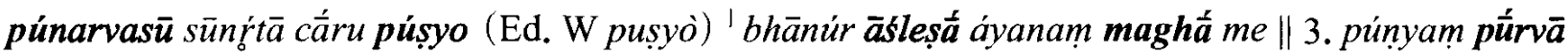

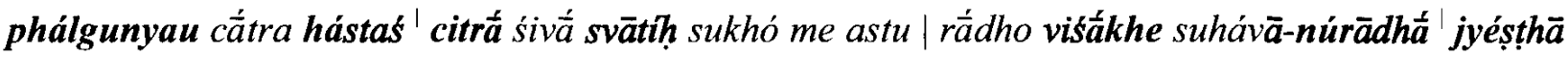

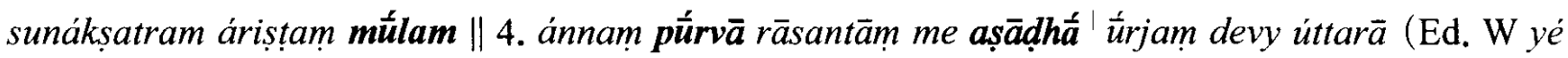
hy úttara) $\stackrel{a}{a}$ vahantu | abhijín me rāsatām púnyam evá 'śávanah śrávișțhāh kurvatām supuștím || 5.

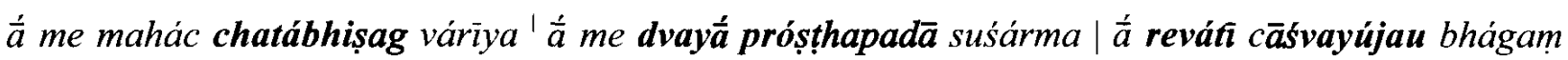
ma' à me rayím bháranya à vahantu

1. To [the Nakssatras which are] conspicuous, shining altogether in heaven, swift and repeating to creep in the universe, desiring protection (? turmiśam; s. above text and n.9) and favor, I pay homage day by day to the celestial vault ( $n a \bar{a} k a-$ ) with songs of welcome. 2. Kớttikās 'spinner women' (No.1: f.pl.) and Róhinī 'reddy (cow)' (No.2: f.sg.) be for me easy to call, Mrgaśiras 'head of a beast (esp. antelope)' (No.3: n.sg.) be lucky, Ārdrấ 'moist woman' (No.4: f.sg.) be auspicious, Púnarvasū 'two men who have again wealth' (No.5: m.du. $\rightarrow 2$.) be virile (sūnŕta-), Púśya 'one who is to blossom' (No.6: m.sg.) be lovely, Āśleșấs 'clinging women' (No.7: f.pl.) be radiance, Maghắs 'well-doing ones' (No.8: m./f.pl.; RV aghă - $\rightarrow$ 2.) be my way! 3. The former [and latter] Phálgunyau 'two pale men' (No.9-10: m.du.; RV árjunī- $\rightarrow$ 2.) and Hásta 'hand' (No.11: m.sg.) be prosperous here, Citrấ 'conspicuous woman' (No.12: f.sg.) be friendly, Svātí 'one who has good ducks' (No.13: m./f.sg.; nișţya- 'outside one' in other lists) be comfortable for me! Višákhe 'twoforked couple' (No. 14: n./f.du.) be success! Anurādhấ 'woman causing welfare' (No.15: f.sg.) be easy to call! Jyéșthā 'the eldest woman (the principal wife)' (No.16: f.sg.) be possessed of a good 
Nakṣatra, Múla 'root' (No.17: n.sg.) be not to be hurt! 4. Let the former Aṣạ̄hắs 'unconquerable women' (No.18: f.pl.; cf. AiGr I 224f.) bestow food upon me, let the latter [Așậ̣hās] (No.19: f.pl.), oh goddess (sg.), bring [me] nourishment! Abhijit 'victorious one' (No.20: m./f.sg.) bestow the very merit upon me! Let Śrávana 'ear' (No.21: m.sg.) and Śrávișthās 'the most famous women' (No.22: f. pl.) produce great prosperity! 5. Let Śatabhișaj 'healer of hundred (persons)' (No.23:m./f.sg.) [bring] me great liberty, let two twofold Próșthapadā 'two twofold feet of a camping bed' (No.24-25:m.f.du.) (4 feet in total) [bring] me good shelter, let Revátī 'wealthy (woman)' (No.26: f.sg. $\rightarrow$ 2.) and Aśvayujau 'two persons who yoke horses' (No.27: m./f.du.) [bring] me a good share, let Bháranyas 'bringing women' (No.28: f.pl.) bring me wealth!

4. The 27-29 Naksatras are enumerated with their divinities in the mantras for the bricks symbolizing each a Nakșatra (nakșatreștakā-) piled on the $5^{\text {th }}$ layer of the fire-alter for the Agnicayana (Agniciti): in the Maitrāyaṇi Samhitā [MS], Kāṭhaka-Saminitā [KS] and Taittirìya-Samhitā [TS] of the Black YV, but neither in the Kapișțhala-Kaṭha-Samhitā, nor the White YV. Cf. the mantras in the Taittiriya-Brāhmana [TB] I 5,1 $(\rightarrow 5$.). For each brick, a Nakșatra, a divinity and a common formula to all the bricks are uttered.

$\mathrm{KS}^{\mathrm{m}}$ XXXIX 13:130,14-131,10 shows the most simple form with 27 Nakṣatras:

agnír devátā. kŕttikā nákṣatram. prajápatir devátāa. rohiṇ̂̉ nákṣatram. ... yamó devátā. apabháranīir nákṣatraì. 'agné rúcah stha. prajápates sómasya dhātúr. bhūyásam prájanișīya. téna bráhmaṇā téna cchándasā táyā devátayā-. ${ }_{a}$ igirasvád dhruvắs sìdata.'

The divinity [of this brick] is Agni, the Nakșatra is Kṛttikās. The divinity is Prajāpati, the Nakṣatra is Rohinîi. ... The divinity is Yama, the Nakșatra is Apabháraṇis. 'You (the Nakṣatra bricks) are radiances of Agni, of Prājāpati, Soma, [and] Dhātr. May I have more descendants! With this formula with realizing power (bráhman-), with this metre, with this divinity, sit (pl.) steadily like Angiras.' (The mantras in quotation marks are repeated for each brick.)

$M^{\mathrm{m}}$ II 13,20:165,12-166,12 mentions 29 Nakṣatras corresponding to a synodic month: kŕttikā nákșatram. agnír devátā-. agné rúcah stha prajápateh sómasya dhātúr. rcé tvā. rucé tvā. bhāsé tvā. jyótịse tvā. téna cchandasā téna bráhmaṇā táyā devátayāngirasvád dhruvấ sīda. rohiṇ̂́ nákșatram. prajápatir devátāa. ... abhijín nákșatram. brahmá devátā. ... bháran̄ìr nákșatram. yamó devátā. brāhamaṇó nákṣatrain. sómo devátā-. agné rúcah stha ... dhruvắ sĩda.

The Nakșatra [of this brick] is Kṛ́ttikās, the divinity is Agni. 'You (pl. the Nakṣatra bricks) are radiances of Agni, of Prājāpati, Soma [and] Dhātr. For the hymn, [I place] you (sg. a Naksatra brick). For the radiance, [I place] you. For the brightness, [I place] you. For the light, [I place] you. With this metre, with this formula with realizing power, with this divinity, sit (sg.) steadily like Angiras.' The Nakṣatra is Rohinî́, the divinity is Prajāpati. ... The Nakṣatra is Abhijít, the divinity is Brahmán ... The Nákșatra is Bháraṇis, the divinity is Yama. The Nakṣatra is Brahmin (brāhamañá-), the divinity is Soma. 'You are radiances ... sit steadly like Añgiras.'

28 Nakșatras are similar with those in the AV. The $29^{\text {th }} \mathrm{N}^{\circ}$ is not a heavenly body but the 
Brahmin on earth, which implies that the moon in the Amāvāsyā night stay with the sun in the sacrificial fire by the Brahmin for the Upavasatha and the New moon sacrifice $(\rightarrow 1$.). Cf. the common concept that the sun stays overnight in the fire ( $R V$ X 88,6; TB ${ }^{\mathrm{p}}$ II $1,2,9$; SB II 3,1,3, etc.). The Brahmin as a Nakșatra appears also TB ${ }^{\mathrm{p}}$ I 5,3,4 $(\rightarrow 6$., Synopsis $)$. The divinity for Abhijít is God Brahmán (masc.), personified from the nt. bráhman-. This suggests relative late origin of this passage (cf. WeBER Naxatra II 379). God Bráhman is attested also in $\mathrm{MS}^{\mathrm{m}}$ II 9,1 [Agniciti] which, however, seems an interpolation from younger texts.

$\operatorname{TS}^{\mathrm{m}}$ IV 4,10,1-3 enumerates 27 Nakșatras but adds two mantras (in pratīka) for Paurnamāsī and Amāvāsyā taken from the New and Full moon sacrifices (TS ${ }^{\mathrm{m}}$ III 5,1ab AV VII 79,$1 ; 80,1$; MānŚS VI 2,3,8) in order to adjust the Nakṣatra number to a synodic month. Both the $2^{\text {nd }}$ and $16^{\text {th }}$ Nakṣatras are called Rohiṇí; Indra appears 3 times as divinity (Citrá, the $16^{\text {th }}$ Rohinî́, Śatabhisaj). The common formulas to all the bricks lack the last important part. All these indicate to the secondary modification made by the Taittiriyas:

kr̆́ttikā nákșatram. agnír devátā-. agné rúca stha. prajăpater dhātúh sómasya. 'rcé tvā dyuté tvā. bhāsé tvāa. jyótiṣe tvā. rohinî́ nákṣatram. prajápatir devátā. ... rohinî́ nákșatram. indro devátā. ... apabháranìr nákșatram. yamó devátā. pūrnạá paścáád. yát te devấádadhuh.

The Nakṣatra [of this brick] is Kị́ttikās, the divinity is Agni. 'You (pl. the Nakṣatra bricks) are radiances of Agni, of Prājāpati, Soma [and] Dhātr. For the hymn ( $\left.\dot{r} c^{-}\right)$, [I place] you (sg. a $N^{\circ}$ brick). For the lightning, [I place] you (sg.). For the brightness, [I place] you (sg.). For the light, [I place] you (sg.).' The Nakṣatra is Rohinî́, the divinity is Prajāpati. ... The $\mathrm{N}^{\circ}$ is Rohinî́, the divinity is Indra. ... The $\mathrm{N}^{\circ}$ is Apabháranis, the divinity is Yama. 'Full in behind (west) ...' (mantra for Paurṇamāsī). 'When the gods fixed you [a share] ...' (mantra for Amāvāsyā).

How to pile the bricks is prescribed in the Śrauta-Sütras, which deviates much or less from the Mantras: [Mānava-ŚS VI 2,3,8 (Maitrāyanīya school)] 13 Nakṣatra bricks + 1 Paurṇamāsī brick + 15 Nakṣatra bricks beginning Višākhe +1 Amāvāsyā brick $=30$ bricks; [Baudhāyana-ŚS X 46 and Āpastamba-ŚS XVII 6,5-10 (Taittirīya school)] the $1^{\text {st }}$ Paurṇamāsī brick + 14 Nakṣatra bricks till Visāākhe + 1 Amāvāsyā brick + 13 Nakṣatra bricks + the $2^{\text {nd }}$ Paurnamāsī brick $=30$ bricks. The 30 bricks symbolize the ideal month of 30 nights ( $\rightarrow$ Ved.Cal. (1) 3.1.). MŚS omits the $29^{\text {th }}$ Naksatra in the MS and cites the hymns for Paurṇamāsī and Amāvāsyā under the influence of the Taittirìyas. In the BŚS and $\bar{A} p S ́ S$, a month begins with the full moon night as in later calendar and two Paurnamāsī bricks are used. In actual performance of the Agnicayana, 30 pebbles (śarkara-) instead of bricks are put on the surface of the $5^{\text {th }}$ layer, since the ŚS prescribes much more than the necessary bricks for the construction of the fire altar (cf. STAAL, Agni I 493-495). The man- 
tras for the Nakṣatra bricks are thus considered as a secondly interpolation taken from the formulas for some secular cult of the Nakșatras such as to be found in TB $^{\mathrm{m}}$ I $5,1(\rightarrow 5$.$) .$

5. TB $^{\mathrm{m}}$ I 5,1 contains 27 Nakșatras with their divinities as well as the mantra-pratikas for Paurnamāāī and Amāvāsyā like TS ${ }^{\mathrm{m}}$ IV 4,10, but lacks the formula common to all the Naksatra bricks. This mantra-collection describes what is yonder (or after) and underneath (or before) each Nakșatra, which concerns popular ceremonies rather than Śrauta rituals. Though long discussed, whether this text belongs to the Agnicayana $(\rightarrow 4$.) or the Nakṣatra-iștis TB III 1 ( $\rightarrow$ 7.) (cf. WeBer nakxtra II 304f.; KeITH TS lxxvi, lxxxii), it is considered to be independent from both the rituals and to serve for another kind of Naksatra worship.

agnéh kṛittikāh $\mid$ śukrám parástāj jyótir avástāt $\mid$... pitrnạạn maghâh | rudántah parástād apabhram śò 'vástāt | aryamnáh púrve phálgunī | jāyá parástād rsṣabhò 'vástāt | bhágasyóttare | vahatávah parástād váhamānā avástāt $\|$... viśveșām devánām úttarāḥ | abhijáyat parástād abhijitam avástāt | ... pūrnạa paścắd yát te devấ ádadhuh $\|$ Kṛ́ttikās belong to Agni. The white-bright one [is] yonder (or: after), the light [is] underneath (or: before).... Maghắs belong to the Fathers. The crying people (in the funeral) [are] yonder, falling down (of the dead) [is] underneath. Two former Pháluguni belong to Aryaman. The wife is yonder, an ox (for the wedding feast) is underneath. Two latter [Phálugunis] belong to Bhaga. The goods as dowry [are] yonder, those who bring [the bride] [are] underneath. ... Two latter [Așāḍắs] belong to the All-gods. What is conquering (nt. abhijáyat) [is] yonder, the conquered (abhijitam) [is] underneath. ... 'Full in behind (west) ...' 'When the gods fixed you [a share] ...' (For the Pháluguni and the marriage, cf. RV X 85,13 [ $\rightarrow$ 1.; Ved.Cal. (1) 3.2.], Kausika-Sūtra 75,5; Āpastamba-Gronyasūtra I 3,1ff.)

6. $\mathrm{TB}^{\mathrm{p}} \mathrm{I} 5,2$ and $\mathrm{I} 5,3$ have no relation to the preceding $\mathrm{TB}^{\mathrm{m}}$ I 5,1 but give various explanations of the Nakșatras which seem to have developed outside the Śrauta rituals: observation of heliacal rising of a Nakșatra probably for the Amāvāsyā night and the following daytime ( $\rightarrow$ Ved.Cal. (1) 2.), Prajāpati composed of Nakṣatras, characteristics of each Nakșatra inclusive of Abhijít, theological etymology of tárakā- and nákșatra- $(\rightarrow$ n. 2), division of the Deva-Nakṣatras (Kọ́ttikās Vișấkhe) and the Yama-N ${ }^{\circ}$ (Anurādhấs Apabháraṇis), auspicious days and day-parts, Brahmin as the $28^{\text {th }}$ Nakṣatra $(\rightarrow 4$., Synopsis), etc.

I 5,2,1ff. yát púnyam nákșatram | tád bát kurvītopavyuṣám | yadá vái sūrya udéti |átha nákșatram naiti $\mid$ yá vati tátra sû́ryo gácchet $\mid$ yátra jaghanyàm paśyet | tấvati kurvìta yatkārí syāt | púnyāha evá kurute | evám ha vái yajñésum ca śatádyumnam ca mātsyó niravasāyayám cakāra \|1\| ... abhijín náa

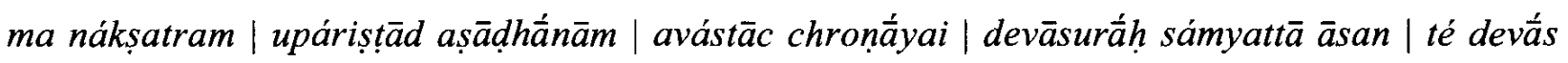
tásmin nákșatre 'bhyàjayan $\|3\|$... What is an auspicious Nakṣatra, one should confirm (bát 'truly/ really!' + kurute; cf. K. Hofmann Aufs. 355) that when the dawn is approaching (just before the sunrise). As soon as the sun rises, [one's sight] does not go to the Naksatra. If there is one who 
does that (astronomical observation) as his task (yatkārí), one should do [one's task], as long as the sun would go where the last [star] would be seen. [It followes that] one does [one's task] on the very auspicious day. In this way, verily, Mātsya made Yajñeșu and Śatadyumna to start from the settlement [for migration] (niravasāyayám cakära; cf. RaU Staat 14).... The Nakṣatra Abhijít by name [is] above (or: after) Aṣāẹhās, and below (or: before) Śroṇā. The Devas and the Asuras were confronted. The Devas conquered at this Nakṣatra. ...

7. TB III 1,1-3 (mantra) and 4-6 (prose) treat the Nakșatra-istis, i.e. the daily offerings to the 28 Nakșatras and the moon, sun, etc. during a month. According to the BaudhŚS XXVIII $3-4$, this ritual begins at the Amāvāsyà night before the full moon situated at the $14^{\text {th }} \mathrm{N}^{\mathrm{c}}$

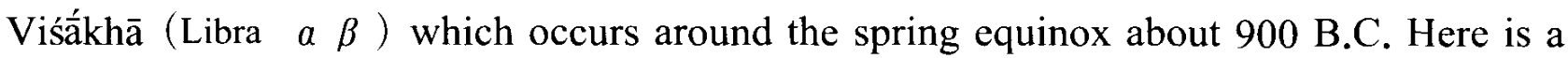
month long festival centering on the full moon at the spring equinox, cf "Passover".

1 ) Cf. AiGr II-2 701ff., 170f. 2 ) The etymology of nákșatra- was variously explained: from naks 'attain (to heaven)' $\mathrm{TB}^{\mathrm{p}}$ I 5,2,5, Nirukta 3,20, GrassmanN; *ná-kșatra- Pāṇini VI 3,75 (comp. with negative $n a ́$; schol. from $k s ̦ a r$ 'flow' or $k s \underline{i}$ 'perish,' i.e. "imperishable"), 'having no governing power' ŚB II 1,2,18f. (cf. Nirukta 3,20); *nakt-tra- "die Nacht schützend" Aufrecht, Weber; *nákt-kṣatra- "Herrschaft über die Nacht habend" Brugmann, AiGr III 233, etc.

In the Jyotisa, the notion of the nákșatra-was transformed into the equally spaced 27 zones of the ecliptic. 4) The 32 stars inclusive of the Pleiades beside the crescent and the full moon are recognized by H. Meller Die Himmelsscheibe von Nebra, Der Geschmidete Himmel 22-31, spec. 28f.; Schmidt-Kaler Acta praehitorica et archacologica 40, 2008, 17f. The Babylonian list of 17 (or 18) constellations that the moon touches (MUL.APIN's list VI, HUNGER and PINGREe MUL. APIN, Archiv für Orientforschung, Bh. 24, 67-71, 144) is dated much later than the other main lists of MUL.APIN and is supposed to have originated under the influence of the Indian Naksatras. For the converse view, cf. Pingree MUL.APIN and Vedic Astronomy, Fs. Sjoberg, 440, 444f. and Hunger and Pingree, Astral Science in Mesopotamia, 31, 72f. Cf. further Chinese "xiu (sieou)" ( 28 unequal divisions of the celestial sphere based on stars near the equator) and Arabian 28 lunar mansions. 5 ) From the elliptic pl. 'stars represented by the Naksatras'; for opposite views, cf. Weber Naxatra Il 267ff., Grassman Wb. RV s.v., Thibeau Astronomy 12f., etc. 6 ) RV tiśyà- corresponds to jav. tišstriia- (m.) name of the star Sirius as divinity, s. Forssman KZ 82, 1968, 57ff. 7 ) Cf. ThIEME Fs. Schneider 329-336 = Kl.Schr. 956-963. 8 ) The view that the 27 Nakșatra system is original to which Abhijit is added is widely shared, cf. WEBER Naxatra II 274-280. 9 ) The number 28 of the Naksatras is mentioned in the following hymn XIX 8,2 (only Śaunaka): aștâvinśáni śiváni śagmáni sahá yógam bhajantu me 'Let the friendly and helpful [Nakșatras] composed of 28 share together in my migration $(\rightarrow 6$.) !'

〈Key words〉 astronomy, calendar, Veda, nákșatra, amāvāsyàa, paurnamāâtí, Agnicayana (ret. Associate Professor, Osaka City University; Dr. de 3ème cycle, Université de Paris III) 


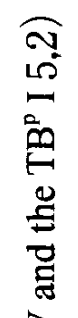

点

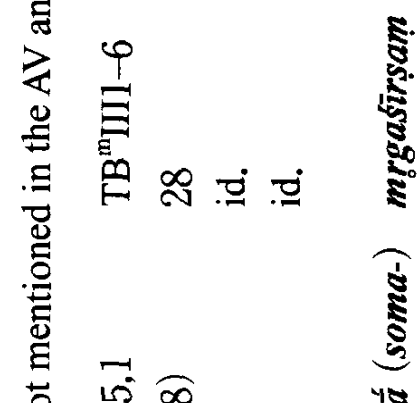

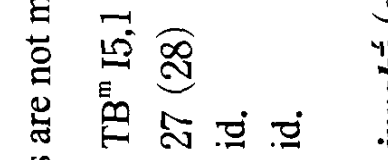

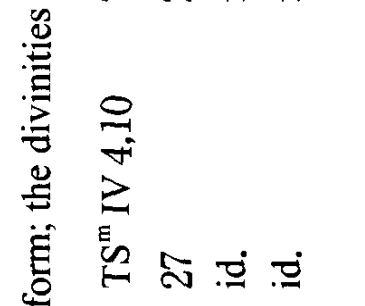

Sิ.

约

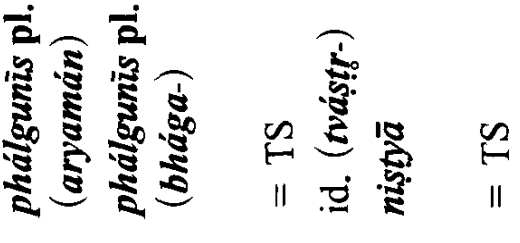
辛

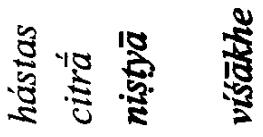

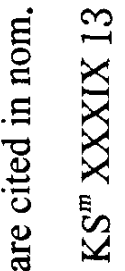

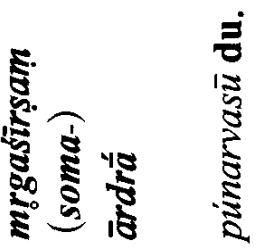

हैं

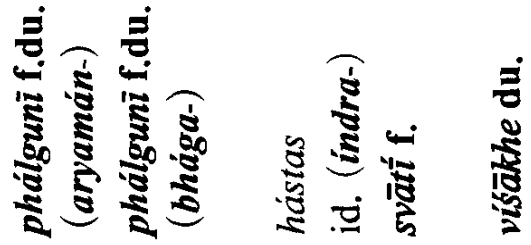

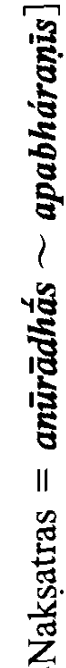

兽

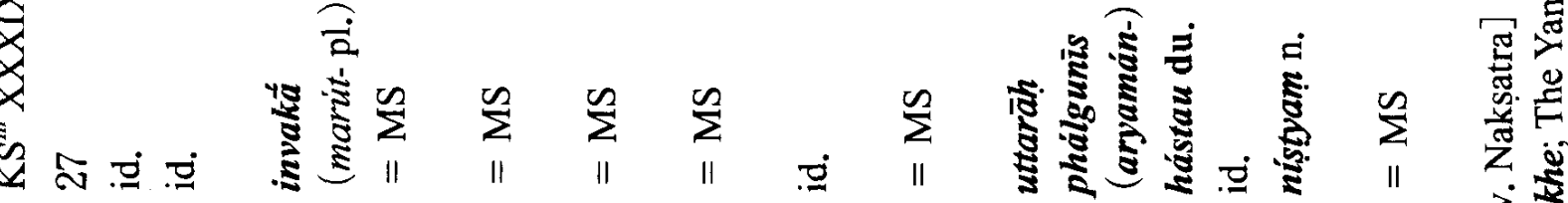

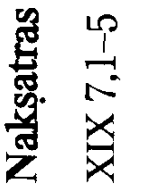

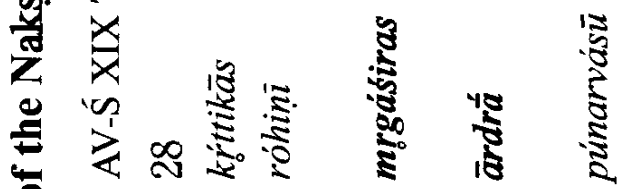

产

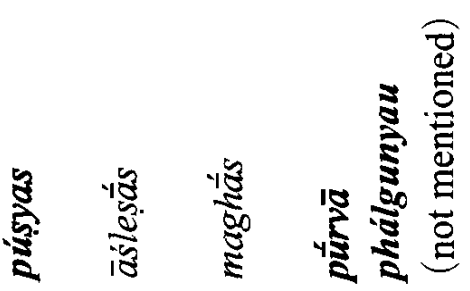

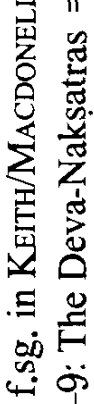

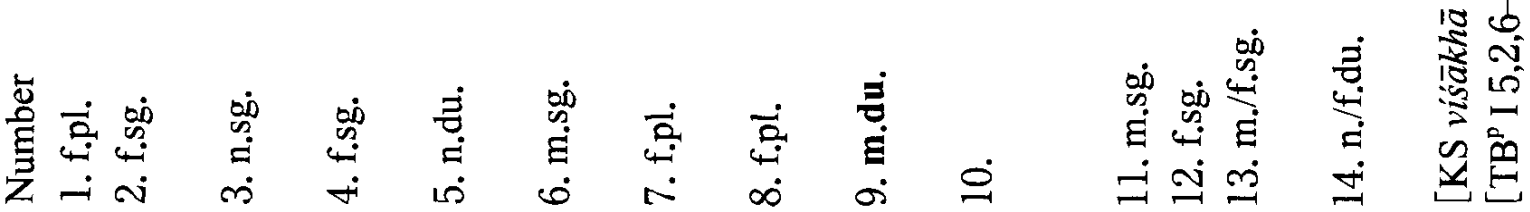




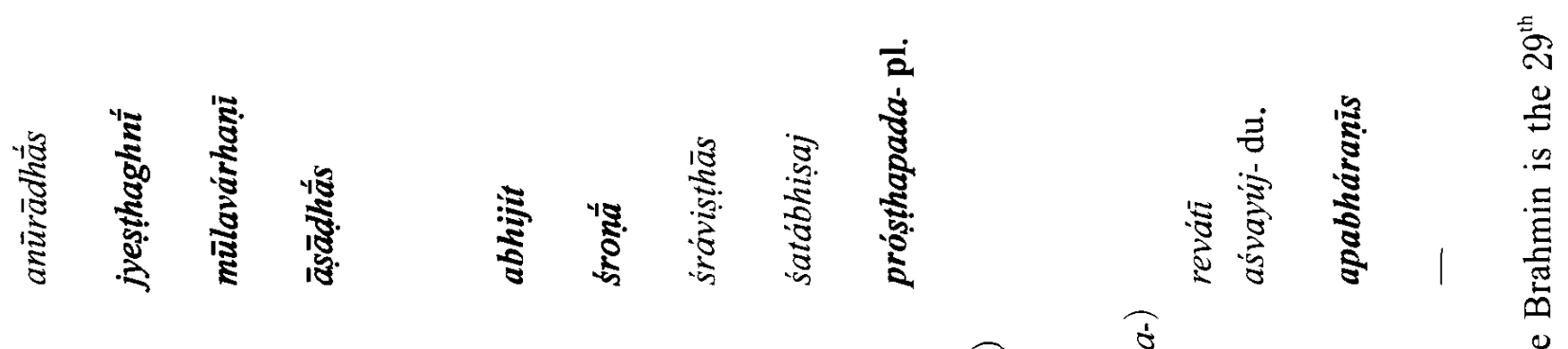

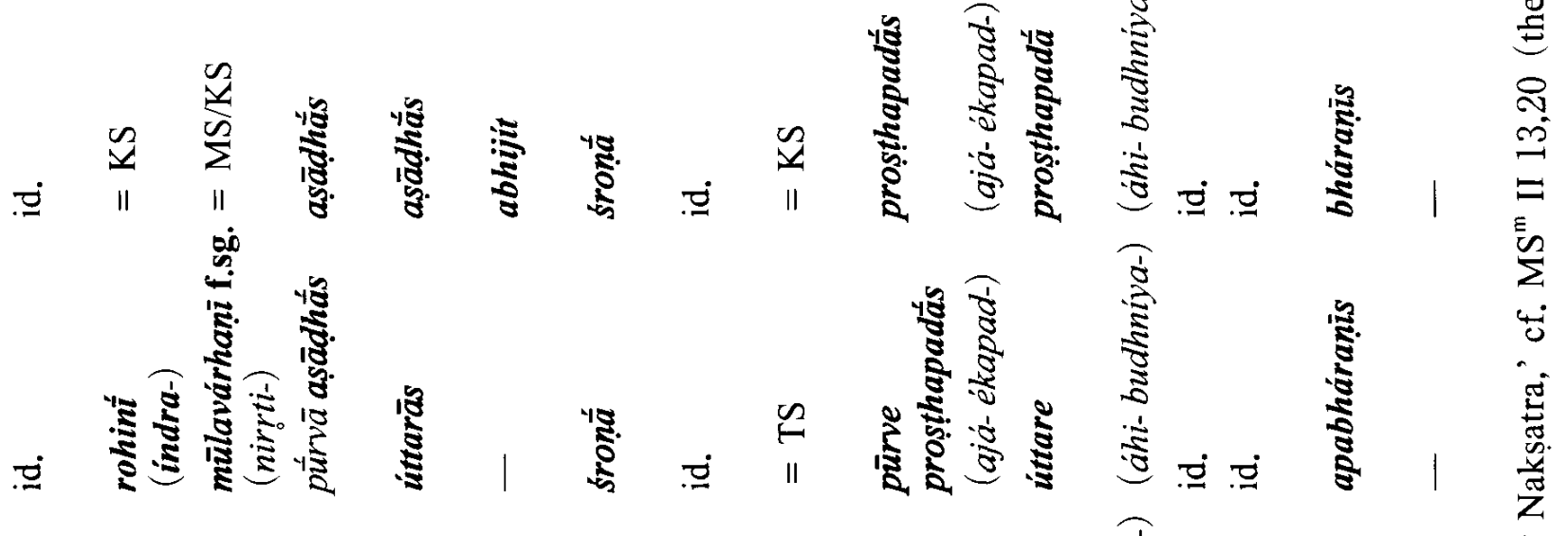
I.

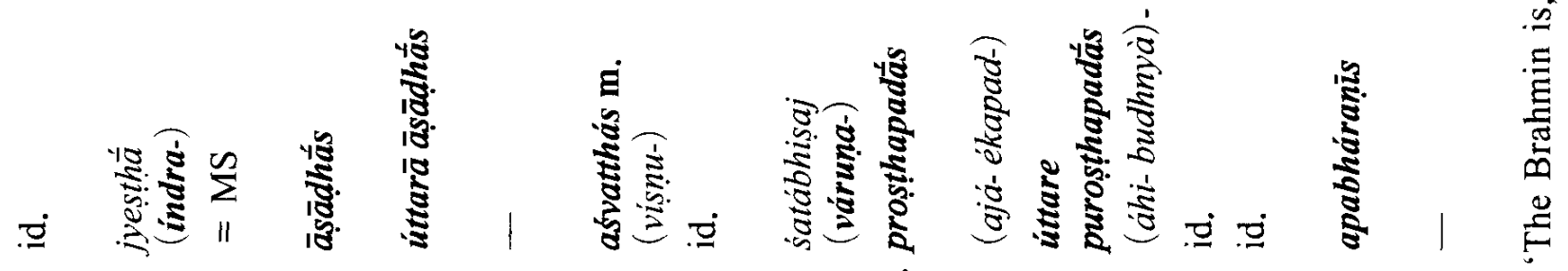

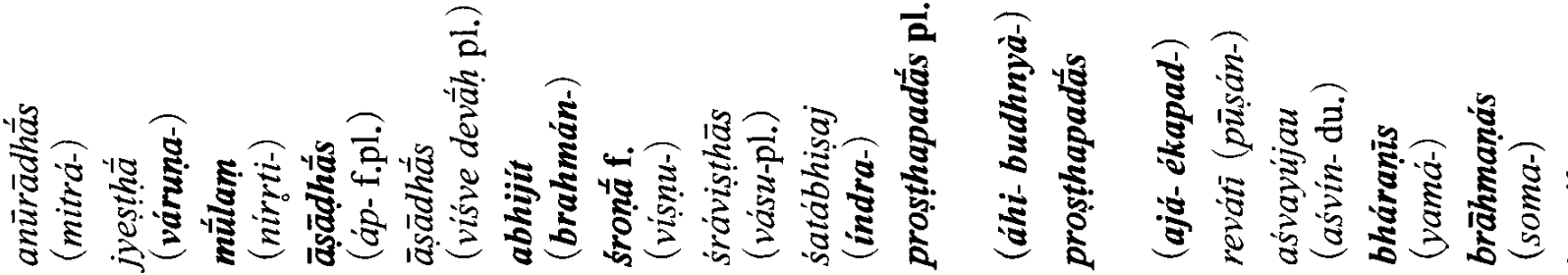

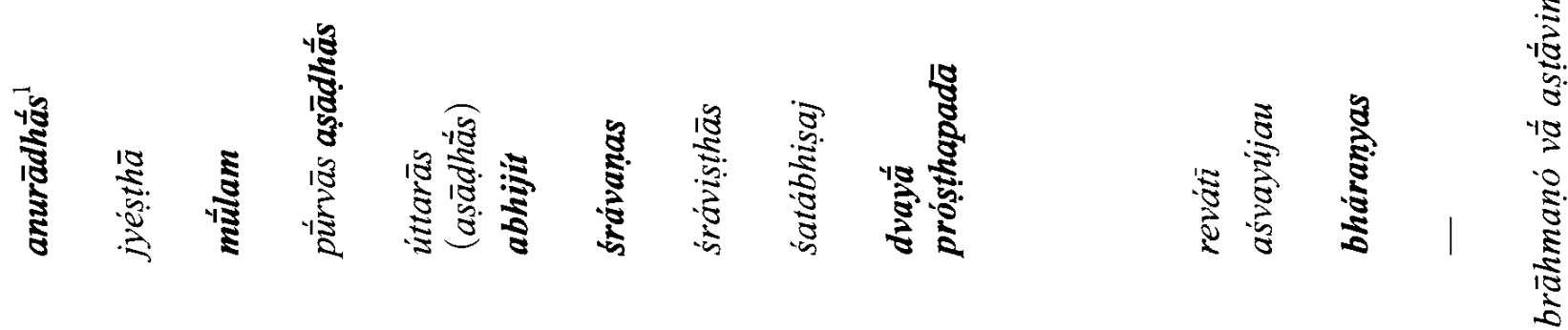

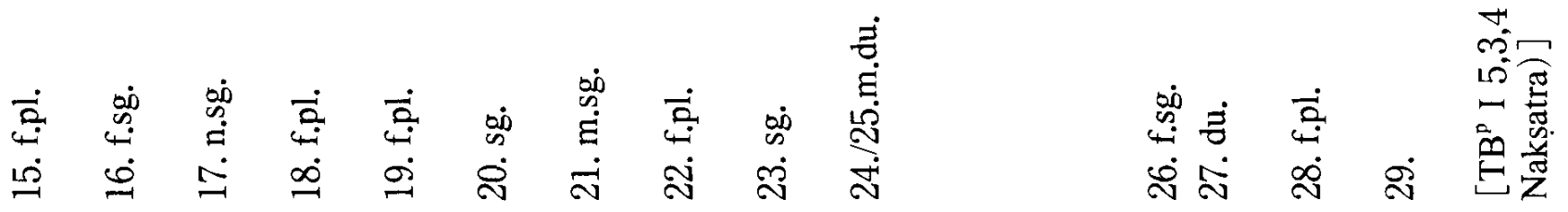

